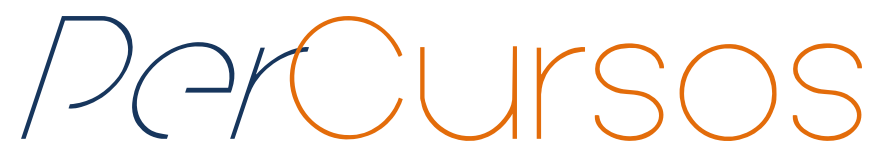

\title{
Espaço e tempo em Xaxim (SC): evolução urbana e desigualdades socioespaciais ${ }^{1}$
}

\begin{abstract}
Resumo
No contexto da urbanização brasileira, muitas pequenas cidades se constituíram histórica e geograficamente de modo socialmente desigual e contraditório, sendo que na atualidade apresentam elevadas assimetrias em sua organização espacial e nas condições de vida de sua população. $O$ presente artigo enfoca uma destas cidades: Xaxim, em Santa Catarina. Realiza-se uma análise das bases histórico-geográficas da ocupação territorial do município e de seu processo de urbanização, bem como de suas principais desigualdades socioespaciais urbanas. Constata-se um espaço urbano marcado por desigualdades, especialmente entre a área central, o assentamento precário do bairro Santa Terezinha e o conjunto de outras áreas residenciais periféricas, situação que submete a população a condições desiguais para se viver (n)a cidade.
\end{abstract}

Palavras-chave: Espaço urbano. Formação histórico-geográfica. Desigualdades socioespaciais. Áreas residenciais. Condições de vida.

\section{Ederson Nascimento}

Doutor em Geografia pela

Universidade Estadual de

Campinas - UNICAMP.

Professor na Universidade

Federal da Fronteira Sul - UFFS,

campus de Chapecó - SC.

Brasil

ederson.nascimento@uffs.edu.br

\section{Mirian Pegoraro}

Licenciada em Geografia pela Universidade Federal da Fronteira Sul - UFFS.

Servidora pública na Prefeitura Municipal de Xaxim - SC. Brasil

mirian.p4@hotmail.com

\section{Para citar este artigo: \\ NASCIMENTO, Ederson; PEGORARO, Mirian. Espaço e tempo em Xaxim (SC): evolução urbana e desigualdades socioespaciais. Revista PerCursos, Florianópolis, v. 20, n.43, p. 315 - 342, maio/ago. 2019.}

\section{DOI: $10.5965 / 1984724620432019315$}

http://dx.doi.org/10.5965/1984724620432019315

\footnotetext{
${ }^{1}$ Os estudos que embasaram a elaboração do presente artigo contaram com apoio da Fundação de Amparo à Pesquisa e Inovação de Santa Catarina (FAPESC), por meio do edital de apoio a projetos de pesquisa (Edital $n^{\circ} 7 / 2015$ ).
} 


\title{
Space and time in Xaxim (the State of Santa Catarina, Brazil): urban evolution and socio-spatial inequalities
}

\begin{abstract}
In the context of Brazilian urbanization, many small cities were historically and geographically constituted in a socially unequal and contradictory way, so that, at the present moment, they have high asymmetries in their spatial organization and in the living conditions of their population. This article focuses on one of these cities: Xaxim, in the State of Santa Catarina (Brazil). An analysis of the historical and geographical fundamentals of territorial occupation of the city and its urbanization process has been undertaken, as well as its main urban socio-spatial inequalities. An urban space marked by inequalities has been verified, notably between the central area, the precarious settlement of the Santa Terezinha neighborhood, and the group of other peripheral residential areas, a situation that subjects the population to unequal conditions to live (in) the city.
\end{abstract}

Keywords: Urban space. Historical-geographical formation. Social inequalities. Residential areas. Life conditions. 


\section{Introdução}

A noção de desigualdade socioespacial se refere à indissociabilidade entre sociedade e espaço na produção de diferenças, rupturas, assimetrias e hierarquias sociais e espaciais, em um movimento único. Envolve a produção socialmente desigual do espaço - sua apropriação, uso e transformação -, cujo movimento ao longo do tempo tende, dialeticamente, a diferenciar e hierarquizar ainda mais o espaço e a própria sociedade (RODRIGUES, 2007). Assim, “A desigualdade socioespacial”, no dizer de Matos (2010, p. 30), resulta “da interação complexa do social e do espacial”.

Dada a natureza socialmente excludente do processo de urbanização levado a cabo no país (MARICATO, 2015; SANTOS, 1993; SANTOS; SILVEIRA, 2001), as cidades estão entre os "níveis" ou "recortes" espaciais do território nacional onde as desigualdades socioespaciais são mais claramente visíveis e apresentam graus de intensidade elevados. O espaço da cidade se caracteriza, entre outros aspectos, por ser desigual e fragmentado em termos sociais e funcionais, o que dá origem a um mosaico irregular com áreas de diferentes tamanhos, formas e conteúdos, assim criadas por distintos processos espaciais e agentes sociais (CORRÊA, 1997).

No contexto brasileiro, dentre as principais instâncias produtoras e mediadoras das desigualdades socioespaciais urbanas, pode-se mencionar os agentes econômicos privados produtores de espaço (proprietários de terras, incorporadores e empreendedores em geral), o poder público, a dinâmica demográfica no contexto do êxodo rural, da (re)distribuição geográfica da população entre cidades e sua distribuiç̧ão diferencial no espaço em função da valorização da terra urbana e da ação dos demais agentes, e, finalmente, a materialidade urbana já consolidada, que influi nas possibilidades de uso da terra e em seus preços no mercado imobiliário. Assim, como bem afirma Rodrigues:

A desigualdade socioespacial exprime formas e conteúdos da apropriação e da propriedade, da mercadoria terra e das edificações, da cidade mercadoria, da exploração e da espoliação da força de trabalho, da acumulação desigual no espaço, da presença e da, aparentemente 
paradoxal, ausência do Estado capitalista no urbano. (RODRIGUES, 2007, p. 74).

Embora, em geral, as desigualdades socioespaciais alcancem maior magnitude nas grandes e médias aglomerações urbanas, em muitas pequenas cidades elas também estão presentes, refletindo (e acirrando) as disparidades de condições de vida de sua população. Apesar disso, essa dimensão da história e da geografia dessas cidades tem sido objeto de poucas pesquisas ${ }^{2}$, ficando, em vários casos, praticamente desconhecidas. A cidade de Xaxim, área de estudo do presente estudo, é um exemplo disso.

Localizado no Oeste de Santa Catarina (Figura 1), o município de Xaxim possui, segundo o IBGE, uma população estimada de 28,4 mil habitantes, com aproximadamente $81,5 \%$ residindo na área urbana. Com uma economia baseada na agroindústria e no comércio, o município detém, para 2010 (ano do último levantamento), um índice de desenvolvimento humano considerado elevado, de 0,752 (com indicadores de 0,737 para renda, 0,662 para educação e 0,871 para longevidade), o qual the confere a $95^{\text {a }}$ posição dentre os 293 munícipios catarinenses, e a $508^{\mathrm{a}}$ posição no contexto nacional (PROGRAMA DAS NAÇÕES UNIDAS PARA O DESENVOLVIMENTO, 2013). Entretanto, esse indicador médio considerado adequado oculta, internamente ao território municipal e, principalmente no espaço urbano, as marcantes disparidades existentes entre as características das áreas residenciais e das condições de vida da população.

\footnotetext{
${ }^{2}$ No caso específico da pesquisa geográfica brasileira, Sposito e Silva (2013, p. 20) salientam que, de modo geral, "o estudo das cidades pequenas não tem sido um dos temas prioritários na produção do conhecimento sobre a cidade [...] as pesquisas tendem a se direcionar para a avaliação das grandes cidades e, mais recentemente, às cidades médias". Ainda segundo esses autores, só a partir do início do século XXI, o quadro de estudos sobre as cidades pequenas passa a ganhar maior representatividade numérica, impulsionado pelo crescimento dos programas de pós-graduação em Geografia em cidades distantes das metrópoles e com características diferenciadas daquelas encontradas nos grandes centros urbanos.
} 
Figura 1 - Localização do munícipio de Xaxim no Estado de Santa Catarina

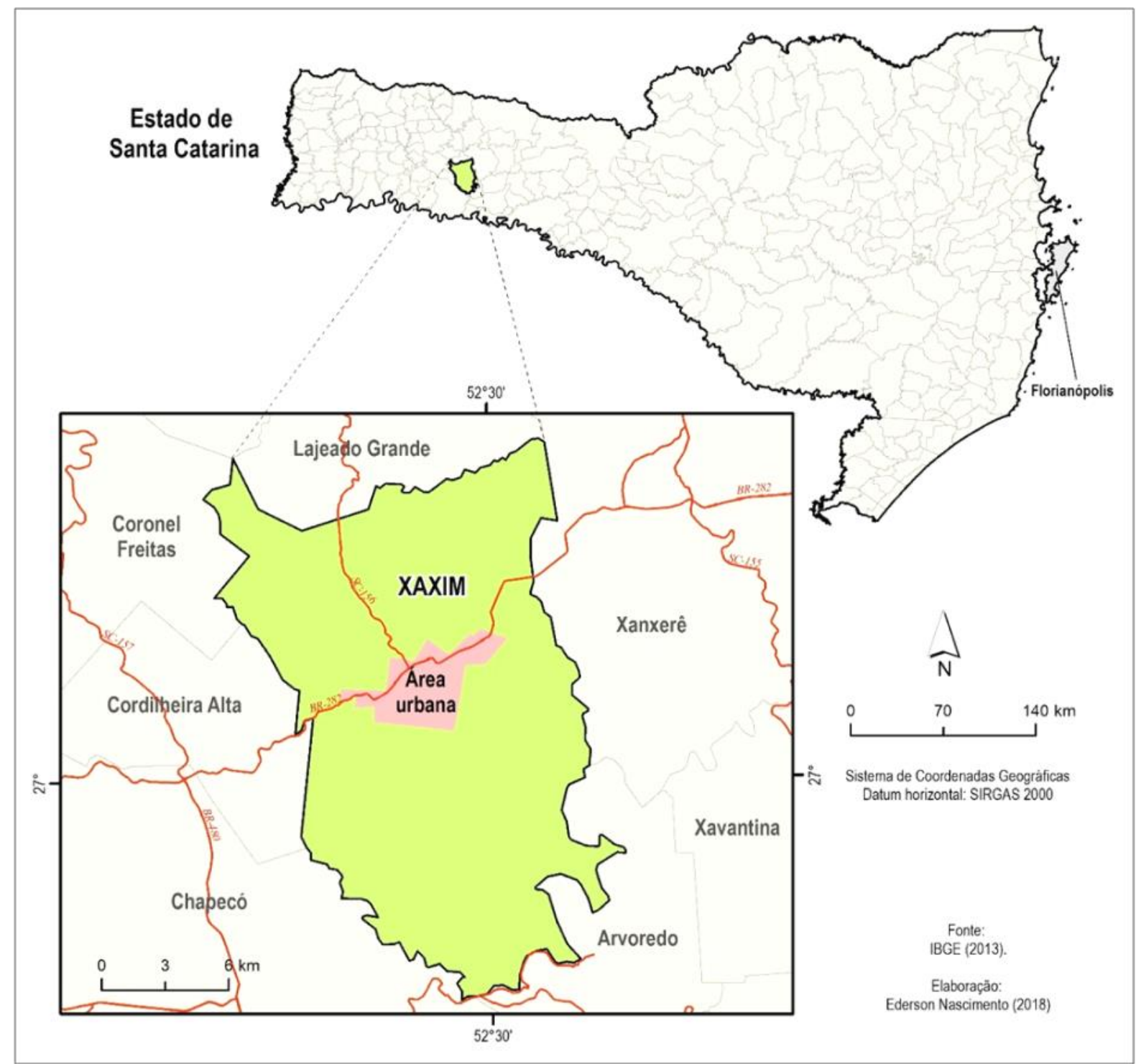

Elaboração: Ederson Nascimento (2019).

Neste contexto, o presente estudo apresenta uma análise da formação históricogeográfica da cidade de Xaxim e suas principais desigualdades socioespaciais na contemporaneidade. Para tanto, elaborou-se o levantamento bibliográfico, de material fotográfico e documental, e de dados sociodemográficos e econômicos, bem como a produção de mapas temáticos, realização de visitas a campo para observações in loco, além de entrevistas com moradores e integrantes da administração pública. Espera-se, com este trabalho, fornecer uma primeira contribuição a fim de ajudar a preencher a referida lacuna existente no conhecimento histórico-geográfico da cidade. 


\section{Formação territorial da cidade de Xaxim}

Ocupada durante séculos originalmente por populações indígenas, o atual município de Xaxim teve seu povoamento iniciado no âmbito da economia tropeira. $\mathrm{O}$ chamado Pouso de Xaxim surge justamente como ponto de parada e pernoite de tropeiros que vinham dos campos de Palmas em direção a Nonoai e Passo Fundo (OLIVEIRA, 1992). No entanto, a efetiva ocupação econômica do território e a aceleração do povoamento deram-se a partir da colonização empresarial empreendida no Oeste catarinense a partir da década de 1920.

Esse processo de colonização foi realizado por companhias colonizadoras privadas, as quais recebiam terras devolutas do Governo do Estado de Santa Catarina. Em troca, essas empresas estabeleciam as bases para a ocupação econômica do espaço, dividindo as glebas em pequenos lotes e comercializando-os, abrindo estradas e fixando as primeiras vilas e núcleos urbanos (PIAZZA, 1994). O modelo de colonização implantado fomentou uma configuração fundiária baseada na pequena propriedade rural e uma estrutura econômica baseada inicialmente na exportação de erva-mate e de madeira, além da produção de gêneros alimentícios voltados à subsistência (PERTILE, 2008). Esse mesmo modelo, porém, processou-se por meio de tensões e conflitos e sociais ao não considerar as populações já presentes na região (posseiros e indígenas), dando origem a um contingente de população expropriada (RENK, 1997) que passa a evoluir praticamente em paralelo à ocupação econômica do território regional.

Nas terras do atual município de Xaxim e em suas proximidades, o processo de colonização se iniciou com a Companhia Colonizadora Bertaso Maia \& Cia, que, após o final da Guerra do Contestado, recebeu do Governo Estadual a concessão de uma área de terras com 288,2 km², em troca da construção da estrada ligando as vilas Passo Goio-En a Passo dos Índios. A referida área, que ficou conhecida como Fazenda Rodeio Bonito, foi colonizada em cerca de mil lotes, que foram vendidos em 1920 para outra empresa colonizadora, a Companhia Irmãos Lunardi (PIAZZA, 1994). Essa empresa viria a ser a responsável pela colonização do território em Xaxim. 
Após a compra das mil colônias, teve início o processo de atração de moradores para a região, principalmente do Rio Grande do Sul. Alguns colonos vinham e ficavam, outros, diante das dificuldades encontradas (sobretudo a inexistência de estradas e estabelecimentos comerciais), não achavam o local atrativo e retornavam ao lugar de onde vieram. No momento da colonização, a principal atividade econômica era a agricultura, notadamente o cultivo de milho e trigo. Com o passar do tempo, a empresa colonizadora viu a necessidade de estabelecer um moinho para o beneficiamento dessas culturas (especialmente a fabricação de farinha), em substituição aos monjolos usados pelos caboclos. Em 1920, foi instalado o primeiro moinho, de propriedade de Antônio Stieven e Silvio Lunardi, o qual, conforme Chitolina (2015, p. 150), "funcionava a energia hidráulica, gerada por uma queda d’água que havia no local".

Em 7 de janeiro de 1921, o passo de Xaxim ou Pouso de Xaxim foi elevado à categoria de distrito de Paz de Hercílio Luz, que pertencia ao munícipio de Chapecó. Nessa época, as casas existentes no distrito tinham característica de serem de madeira falquejada, de um ou dois andares, cobertas com pequenas tábuas (CHITOLINA, 2015). Foi por volta do ano de 1926 que se iniciou a atividade comercial, quando foi fundada a primeira casa comercial de Sílvio e Ambrosina Lunardi, que compravam produtos agrícolas e realizavam a venda de secos e molhados. Além dos moinhos e da atividade comercial, os colonizadores desenvolveram a atividade extrativa da erva-mate, atividade esta já realizada outrora por caboclos (OLIVEIRA, 1992).

Elevado à categoria de distrito no ano de 1929, Xaxim ganhou destaque na extração de madeira, que entre 1930 e 1950 teve grande importância para a economia local. A vasta disponibilidade de mata nativa foi um dos fatores que colaborou para a implantação de pequenas indústrias extrativas de madeira no distrito. De acordo com Chitolina:

[...] somente no território colonizado pela família Lunardi surgiram dezenas de pequenas indústrias extrativas de madeiras. A atividade cresceu tanto que se tornou um dos principais setores econômicos do distrito. Dezenas de pequenas indústrias, com equipes de trabalho bem estruturadas, faziam desde a derrubada dos pinheiros e o arrasto das 
toras até o trabalho aprimorado dos serradores. (CHITOLINA, 2015, p. 141).

Devido à inexistência de estradas, o escoamento da madeira cortada era feito pelo rio Uruguai em balsas, até a Argentina, onde era comercializada. As toras e tábuas seguiam até o Goio-En por caravanas de carroções de mulas ou de bois, em meio aos precários caminhos abertos no meio da mata (BELLANI, 2014). A condição limitante imposta pela falta de estradas "[...] fez com que Luiz Lunardi no ano de 1929 solicitasse a Adolfo Konder, que era governador [do Estado], a implantação da estrada entre Xaxim e Joaçaba" (CHITOLINA, 2015, p. 114). A estrada, porém, foi construída só no ano de 1937, a qual viria a constituir, quatro décadas mais tarde, um trecho da BR-282, que contribuiu para o desenvolvimento econômico da região.

No início dos anos 1940, um núcleo urbano inicial começa a se formar com a criação de estabelecimentos comerciais e de serviços junto ao aglomerado de casas. Em 1942, há o registro da existência de cinco estabelecimentos comerciais de gêneros alimentícios, quatro serrarias a vapor para exploração de madeira, uma selaria, uma ferraria, uma alfaiataria e casa de pasto, um bar, duas fábricas de bebidas, uma farmácia, um hotel, uma sapataria e um frigorífico de suínos e derivados. Destaca-se, nessa mesma época, o Frigorífico Diadema, criado em 1939, que realizava o abate de suínos. Segundo Oliveira (1992, p. 124), “o frigorífico Diadema produzia banha, salame, fiambre que levavam as marcas "Lunardi e Regência”, vendidos para o mercado catarinense e diversos outros países." O transporte inicial dos produtos industrializados era realizado “por caminhões até o porto de São Francisco e lá embarcados em navios para São Paulo e Rio de Janeiro, ou eram levados de caminhão até a antiga Cruzeiro, hoje Joaçaba, com destino a São Paulo" (OLIVEIRA, 1992, p. 124). O frigorífico Diadema deu um grande impulso à economia local, o que contribuiu para a atração de um número maior de migrantes na década de 1940, contribuindo para o crescimento da vila (Figura 2).

No decênio seguinte, já se percebe um maior desenvolvimento do distrito de Xaxim. Diversos estabelecimentos industriais e comerciais instalados, as ruas, mesmo sendo de terra, já possibilitavam maior deslocamento. Segundo Chitolina (2015, p. 159), 
“A produção industrial no ano de 1950 estava voltada principalmente na produção de banha, carne, salame, mortadela, linguiças e salsichas não enlatadas." Além do frigorífico, o distrito contava na época com serrarias, indústria ervateira, olaria e mecânica.

Com o desenvolvimento do distrito, crescia o movimento para a emancipação político-administrativa em relação a Chapecó, o que acabou ocorrendo em dezembro de 1953. O novo município de Xaxim, anos depois, também perderia território, com a criação dos municípios de Galvão e São Domingos, em $1963^{3}$.

Figura 2 - Vista do núcleo urbano de Xaxim, sentido sul-norte, em 1950: ao centro, é possível identificar a Igreja Matriz e a praça central

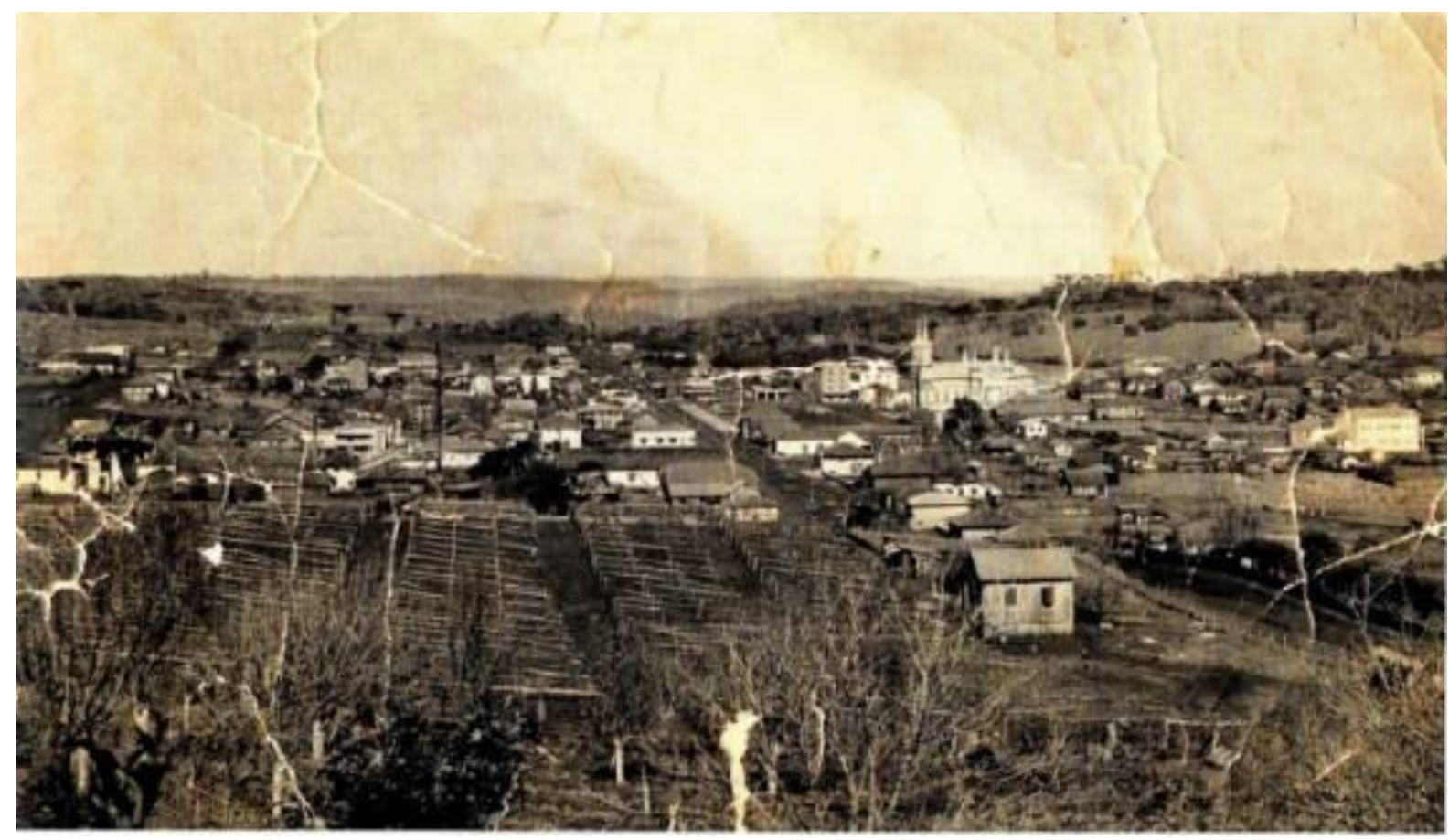

Fonte: Chitolina (2016, p. 39).

Nos anos 1960, grande parte dos ganhos da economia xaxiense provinha da agricultura, principalmente dos cultivos de feijão, trigo, milho e da criação de suínos. Até o ano de 1963, o frigorífico Diadema esteve em funcionamento e em plena expansão, quando então foi vendido para a S/A Indústria e Comércio SAIC, de Chapecó. Com o

\footnotetext{
3 Posteriormente, outras duas emancipações municipais ocorreram a partir do território de Xaxim: Marema (1989) e Lajeado Grande (1993).
} 
passar dos anos, a unidade foi ampliada, aumentando o abate de suínos, o que proporcionou o crescimento do número de empregos diretos e indiretos e gerou efeitos multiplicadores sobre outros setores da economia local. Em 1976, a Chapecó Alimentos iniciou suas atividades na cidade no ramo da avicultura, dando novo impulso ao setor agroindustrial local.

Em tal contexto, a dinâmica populacional no município também passou a sofrer importantes alterações com o avanço da urbanização. Os dados reunidos na Tabela 1 mostram que em 1960, antes, portanto, das emancipações municipais, a população total de Xaxim era de 20,6 mil habitantes, com 90,4\% dela residindo nas áreas urbanas da sede e demais distritos. Em 1970, após as emancipações, a população total apresenta pequeno recuo (20 mil), voltando a crescer ao longo do decênio e atingindo 24,5 mil em 1980. Os censos demográficos seguintes mostram certa estabilidade desse número: 21,3 mil em 1991, 22,9 mil em 2000, e 25,7 mil em 2010. Entretanto, ocorre um rearranjo da população no território a partir da década de 1960, com um esvaziamento do campo e concomitante aumento da população residente no espaço urbano - tanto em termos percentuais, como em números absolutos (Tabela 1).

Tabela 1 - Evolução da população no município de Xaxim (1950-2010)

\begin{tabular}{|c|c|c|c|c|c|}
\hline Ano & População urbana & $\%$ & População rural & $\%$ & Total \\
\hline 1950 & 1.329 & 9,8 & 12.181 & 90,2 & 13.510 \\
\hline 1960 & 1.990 & 9,6 & 18.646 & 90,4 & 20.636 \\
\hline 1970 & 4.271 & 21,3 & 15.804 & 78,7 & 20.075 \\
\hline 1980 & 6.868 & 28,0 & 17.636 & 72,0 & 24.504 \\
\hline 1991 & 10.501 & 49,3 & 10.797 & 50,7 & 21.298 \\
\hline 2000 & 16.058 & 70,3 & 6.799 & 29,7 & 22.857 \\
\hline 2010 & 20.967 & 81,5 & 4.746 & 18,5 & 25.713 \\
\hline
\end{tabular}

Fonte: Elaborado pelos autores com base em IBGE (censos demográficos de 1950 a 2010).

Essa dinâmica territorial da população é explicada, sobretudo, por dois fatores: o êxodo da população rural, desencadeado pela crescente modernização da produção agropecuária regional, a permanência, no espaço rural, de pequenos produtores e/ou seus descendentes, bem como de trabalhadores que não dispõem de terras (ALBA, 2013; 
ALVES; MATTEI, 2006), e; o crescimento das atividades econômicas no espaço urbano, que passam a representar, aos olhos dos migrantes, maiores oportunidades de emprego e renda e melhor qualidade de vida.

A partir da década de 1980, a cidade passa a crescer mais rapidamente, da canalização do rio Xaxim na zona central, o que propiciou a valorização dessa área e a construção de prédios para usos comerciais e residenciais de modo conjugado. São implantados também novos loteamentos, contribuindo para a expansão horizontal urbana.

A comparação entre as imagens aéreas de 1978 e 2017, exibidas a seguir, nos permite ter noção do crescimento do tecido urbano e suas principais alterações. Observase que em 1978, além de a área urbanizada ser bem menor (aproximadamente 2,93 $\left.\mathrm{km}^{2}\right)^{4}$, a ocupação do solo mostrava-se bastante discrepante, com maiores densidades na zona central e elevada rarefação nas áreas periféricas (Figura 3). Por sua vez, nas décadas que se seguiram, o tecido urbano xaxiense se expandiu $\left(9,54 \mathrm{~km}^{2}\right.$ em 2017), inclusive ultrapassando o limite norte da rodovia BR-282, além de aumentar as densidades de ocupação (Figura 4).

${ }^{4} \mathrm{O}$ cálculo da extensão do tecido urbano foi realizado por nós empregando a técnica analítica de cálculo de área, utilizando o software de geoprocessamento ArCGIS®. 
Figura 3 - Vista da área urbanizada de Xaxim (delimitada em laranja), em fotografia aérea de 1978

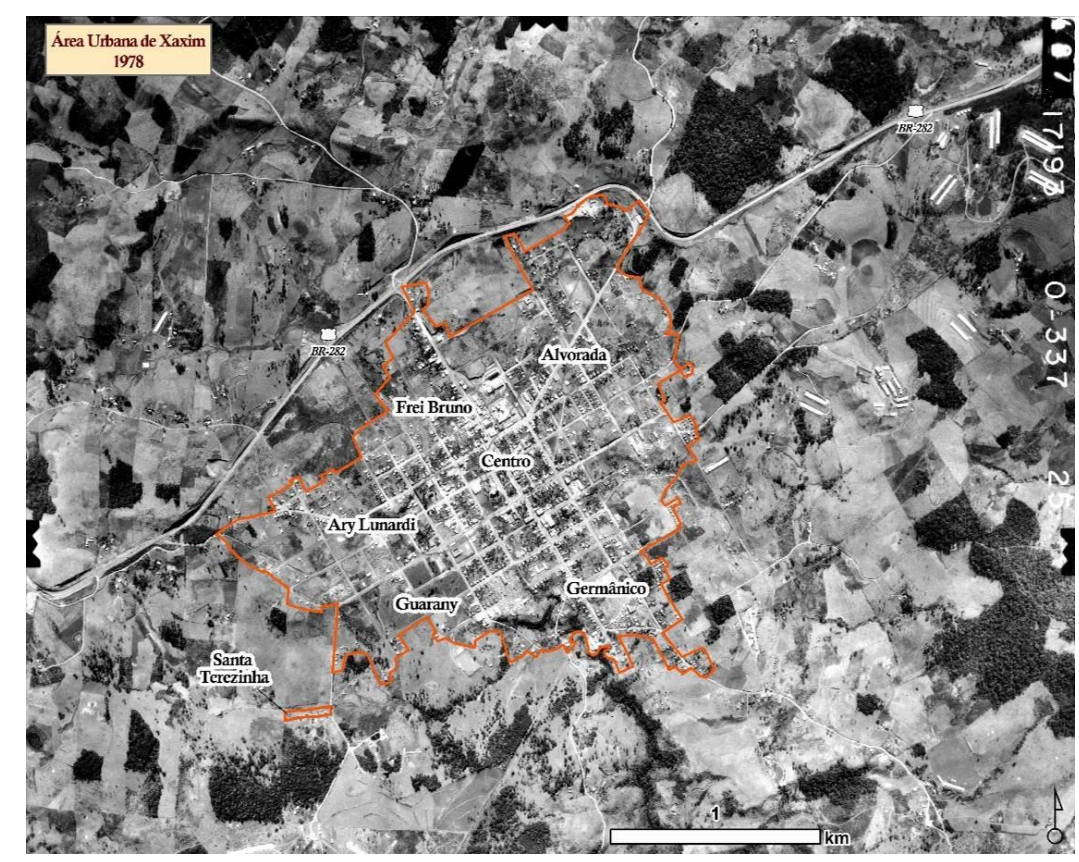

Fonte: Secretaria de Estado do Desenvolvimento Sustentável de Santa Catarina - SDS/SC. Edição cartográfica: Ederson Nascimento (2018).

Figura 4 - Vista da área urbanizada de Xaxim (delimitada em laranja), em imagem de satélite de 2017

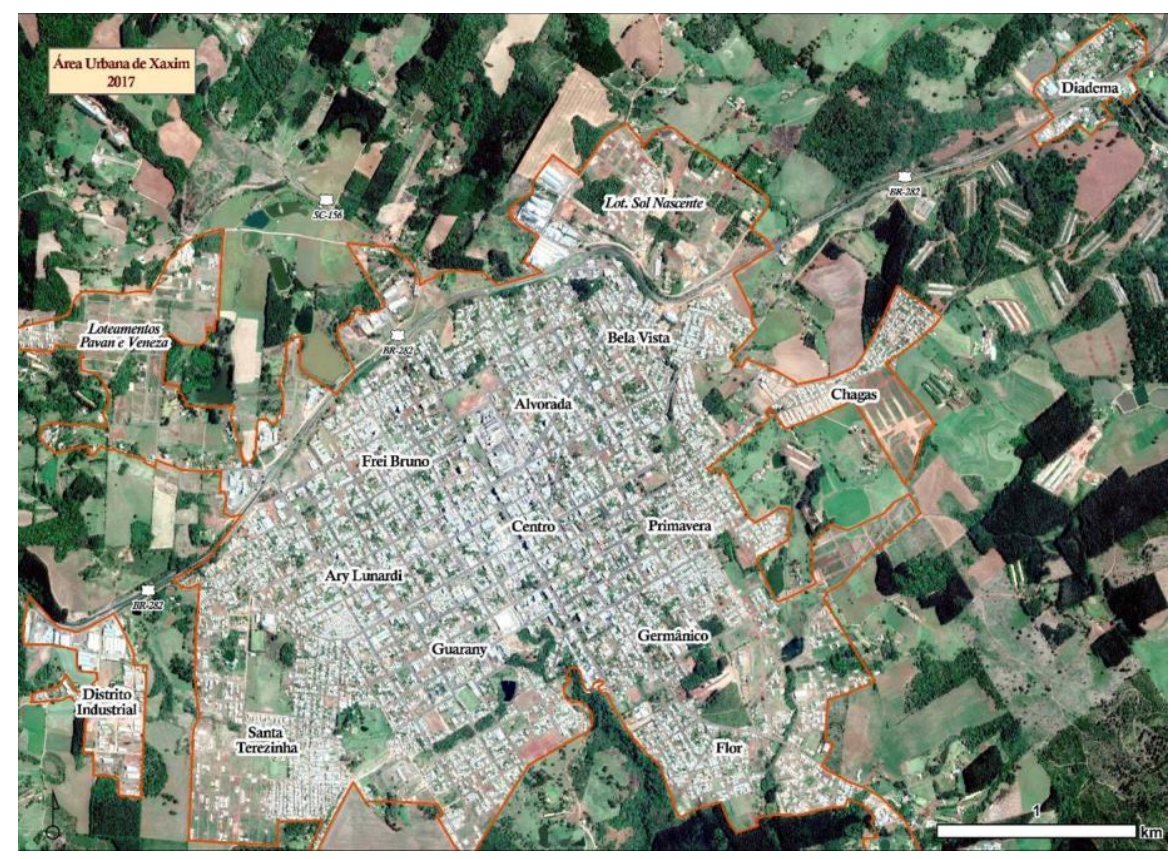

Fonte da imagem: Google Earth.

Edição cartográfica: Ederson Nascimento (2018). 
Ademais, as características socioespaciais das áreas residenciais passaram a se diferenciar crescentemente, com o surgimento de loteamentos precários em infraestrutura e serviços, afastados da área central. Há registro de problemas com subhabitações irregulares em Xaxim já no fim da década de 1970. De acordo com informações de Scherer, Fujita e Rigon (2012), e de relatos de moradores da cidade, naquele momento havia famílias instaladas de modo irregular em um terreno da prefeitura municipal nas proximidades da rodoviária, e também na faixa de domínio da BR-282. Eram pessoas que trabalhavam principalmente com o corte de erva-mate, conhecidas como boias-frias, e cuja remuneração era recebida por dia trabalhado. Essa população era principalmente de origem cabocla, trabalhadores expropriados do campo que, aos olhos da elite agroindustrial, não serviam para o trabalho nos frigoríficos (por isso, a agroindústria priorizava migrantes de origem ítalo-alemã), de modo que precisavam se submeter ao árduo trabalho braçal no campo e com baixíssima remuneração (CURTARELLI, 2017. Informação verbal).

A municipalidade realocou a população para um outro loteamento, situado a sudoeste e afastado da malha urbana (Cf. Figura 4), onde atualmente é o bairro Santa Terezinha. A prefeitura construiu as casas e forneceu escrituras dos imóveis, porém o loteamento já nasceu com condições de habitabilidade precárias:

O loteamento em questão foi projetado em áreas de domínio público, com a implantação de infraestrutura mínima, como abertura de ruas, demarcação de lotes para habitação de interesse social unifamiliar e execução de casas em madeira de $24,00 \mathrm{~m}^{2}$ sem módulo sanitário, com energia elétrica e água chegando à entrada do lote. (SCHERER; FUJITA; RIGON, 2012, p. 6).

O bairro cresceu anos depois, com a incorporação de cem casas de alvenaria, de aproximadamente $40 \mathrm{~m}^{2}$ cada, financiadas pela antiga COHAB (Companhia de Habitação do Estado de Santa (atrina), e se densificou ainda mais com a ampliação das construções já existentes e a criação de novas casas (a maioria delas precárias) anexas àquelas. Entretanto, a dotação de infraestrutura e de serviços não acompanhou esse crescimento, 
ficando muito aquém das necessidades da população. Assim, ao longo do tempo, essa área residencial acabou se consolidando - como veremos na seção seguinte - como o principal locus de exclusão social (COSTA, 1998) da cidade, com elevada precariedade em infraestrutura e serviços e com grande carência socioeconômica de sua população. Esses eventos demarcam, pois, uma das raízes da segregação socioespacial na cidade de Xaxim, vinculada à exclusão social acometida sobre essa população, resultado da sobreposição de carências socioeconômicas e subjugações psicossociais.

A partir da década de 1990, não obstante a recessão que atingia praticamente todo o Brasil, Xaxim recebeu outras importantes empresas, como a Isofer Isolamentos e Funilarias, Benova Alimentos Ltda., e Tronic Materiais Esportivos. Houve a criação de novos loteamentos e maior incremento populacional na área urbana (Cf. Tabela 1). Porém, uma grave crise econômica é desencadeada no final do decênio devido ao declínio da principal empresa instalada no município, a Chapecó Alimentos. De acordo com Skrzypczak:

Em meio a sucessivas crises e má administração, no ano de 1998 o Grupo Chapecó foi adquirido pelo Grupo Macri da Argentina [...]. Após a aquisição a empresa momentaneamente se equilibrou, porém o próprio grupo argentino, em crise também não conseguiu administrar a situação que desencadeou uma nova crise na empresa Chapecó Alimentos devido ao endividamento e a falta de capital de giro. (SKRZYPCZAK, 2013, p. 56).

A empresa encerrou suas atividades em 2003, após entrar em concordata, acarretando a demissão de aproximadamente 4,6 mil funcionários e causando forte impacto negativo sobre a economia local. Em entrevista a um portal de notícias da cidade, um ex-funcionário da Chapecó Alimentos descreve o cenário de estagnação visível na cidade:

A Chapecó ficou parada oito meses na cidade, parecia um deserto isso aqui. Sinceramente, você ia à cidade e dava uma tristeza, porque todo o comércio estava parado [...]. O que ia ter? Empresas pequenas que vendiam algumas coisas, mas o restante da cidade era um deserto. [...] 
Teve muitas pessoas que se obrigaram a ir embora, mas outros ficaram no município. ${ }^{5}$

Em dezembro de 2003, a empresa Diplomata, de Cascavel (PR), arrendou o frigorífico e reiniciou suas atividades, com abate de frangos, fabricação de rações e produção de matrizes, empregando cerca de quatro mil trabalhadores, além de mil produtores integrados (SKRZYPCZAK, 2013).

A economia do município teve um novo impulso na sequência dos anos 2000, devido à ascensão da referida empresa e a outros investimentos, como a criação, pela municipalidade, do Distrito Industrial Lunardi, às margens da BR-282, a instalação de outras importantes indústrias, e a implantação do campus da Faculdade Celer. "Os setores de comércio e serviços obtiveram um crescimento significativo [...] tornando o município mais atrativo a profissionais liberais, em especial na área da saúde" (SCHERER; FUJITA; RIGON, 2012, p. 5).

As populações urbana e total cresceram - respectivamente, de 16,1 mil e 22,6 mil em 2000, para 21 mil e 25,7 mil em 2010 (Cf. Tabela 1), impulsionadas principalmente pelo saldo migratório positivo ${ }^{6}$. Na área urbana, novos loteamentos foram aprovados, nos bairros Bela Vista, Chagas, Guarany, Primavera, Flor, Santa Terezinha e em áreas ao norte da BR-282, fora da delimitação formal de bairros da cidade (loteamentos Sol Nascente, Pavan e Veneza) (vide Figura 4).

De 2011 em diante, Xaxim intercalou períodos de estabilidade e de recessão econômica. O frigorífico Diplomata, que ainda ocupava papel de destaque na economia local, entrou em crise e fechou as portas em 2012, deixando um enorme volume de dívidas junto a ex-funcionários, avicultores, transportadoras, além de outros credores. $\mathrm{O}$ impacto negativo sobre o emprego e a renda foram em parte contrabalançados com a assumpção de atividades do referido frigorífico pela Aurora Alimentos ${ }^{7}$, bem como por

\footnotetext{
5 Declaração do Sr. Valdemar Mendo, ex-funcionário da unidade da Chapecó Alimentos de Xaxim, reproduzida em entrevista ao portal Lê Notícias (2017).

${ }^{6}$ De acordo com dados do IBGE, em 2010, 1.900 dos 25.713 habitantes não residiam no município cinco anos antes (taxa de migração de $7,4 \%$ ).

7 No fim de 2012, a Coopercentral Aurora Alimentos arrendou a unidade industrial de abate e processamento de aves, retomando parte de suas atividades. Entretanto, as dívidas do Grupo Diplomata
} 
outros negócios, como a ampliação da Cooperativa Agroindustrial Alfa, e o crescimento do setor da construção civil impulsionado pela ampliação de linhas de financiamento imobiliário. Os dados mais recentes sobre emprego e renda, de 2016, apontam uma taxa de ocupação de 37,6 \% em relação à população total (que naquele ano era de 27,9 mil habitantes), sendo que a renda média mensal era de 2,2 salários mínimos. No entanto, se considerarmos a população com baixa renda (com rendimento mensal per capital de até meio salário mínimo), veremos que seu percentual é elevado nesse mesmo ano (15,8\%), mas inferior ao de 2010 (24,8\%) (BRASIL, 2016; IBGE, 2010).

A infraestrutura urbana apresenta carências. A taxa de urbanização de vias públicas medida pelo IBGE, de 19,3\%, é uma das mais baixas de Santa Catarina, e o índice de esgotamento sanitário adequado atingia apenas 49,4\% da população (IBGE, 2010) ${ }^{8}$. Esses índices apresentam discrepâncias no território municipal, sendo que no espaço urbano há disparidades expressivas entre as áreas centrais e as situadas na periferia, e mesmo dentro destas últimas entre si.

\section{Xaxim: a cidade e suas desigualdades socioespaciais}

Uma das possibilidades para se analisar as desigualdades socioespaciais urbanas consiste em apreendê-las a partir das divisões funcionais e sociais que, como bem esclarece Corrêa (2007), caracterizam o espaço urbano. Significa, pois, caracterizar a distribuição dos principais usos da terra, tipificando os espaços da atividade econômica (da produção, circulação e consumo) e os espaços da moradia e lazer (incluindo, neste

ainda não foram quitadas. Em fevereiro de 2018, a empresa aprovou, junto aos credores, um plano de recuperação judicial, que prevê o pagamento das dívidas em um período de até 15 anos.

${ }^{8}$ Urbanização de vias públicas: [domicílios urbanos em face de quadra com boca de lobo e pavimentação e meio-fio e calçada / domicílios urbanos totais] x 100. Esgotamento sanitário adequado: [população total residente nos domicílios particulares permanentes com esgotamento sanitário do tipo rede geral e fossa séptica / população total residente nos domicílios particulares permanentes] x 100 (Cf. IBGE, 2010). Ainda quanto ao esgotamento sanitário, segundo o Atlas Esgotos da Agência Nacional de Águas, em 2013, 43,9\% da população não dispunha de qualquer serviço de coleta de esgoto, enquanto outros 42,7\% dispunham de fossa séptica (solução individual) e 13,4\% têm o esgoto coletado mas não tratado (AGÊNCIA NACIONAL DE ÁGUAS, 2017). Os dados disponibilizados na referida pesquisa não permitem a diferenciação por zona urbana e rural, e tampouco por bairros da cidade. 
âmbito, a distribuição geográfica da população), nos quais se realiza a reprodução da força de trabalho e das classes sociais.

Um primeiro enfoque, que auxiliará na interpretação dos demais temas, deve ser direcionado à espacialização da população. O mapa de densidades demográficas exibido a seguir (Figura 5), nos mostra que há uma diversidade de densidades, sendo que as mais elevadas (acima de 50 habitantes por hectare) estão nos bairros periféricos Chagas e Santa Terezinha, seguidos pelos bairros Frei Bruno, Bela Vista, Primavera, Germânico e Ary Lunardi, além de parte do Centro, todos com densidades entre 30 e 50 habitantes por hectare. Enquanto, de modo geral, as elevadas densidades demográficas nos bairros citados se devem à concentração de residências ocupadas em terrenos menores, no Centro está associada à maior verticalização.

Em termos funcionais, o espaço urbano de Xaxim é dividido em três grandes tipos de usos da terra: os espaços industriais, os espaços comerciais, que, em sua maioria, mesclam-se com usos residenciais, sendo assim usos mistos, e as áreas predominantemente habitacionais. O zoneamento de uso e ocupação do solo do plano diretor municipal em vigor (XAXIM, 2014) reproduz, grosso modo, essa divisão. Como se pode observar na Figura 6, a Zona de Interesse Industrial (ZII) inclui as áreas do distrito industrial e outras às margens da BR-282, as quais são estratégicas para o fluxo territorial de matérias-primas e mercadorias produzidas. Já a atividade comercial se concentra em um eixo sul-norte, partindo do Centro em direção ao bairro Alvorada (Zona Comercial Predominante - ZCP), e também ao longo de dois eixos viários (Zonas de Corredor Comercial - ZCC) nos bairros Ary Lunardi e Bela Vista, partindo do Centro em direção à BR-282 (Figura 6). 
Figura 5 - Densidades demográficas na área urbana de Xaxim

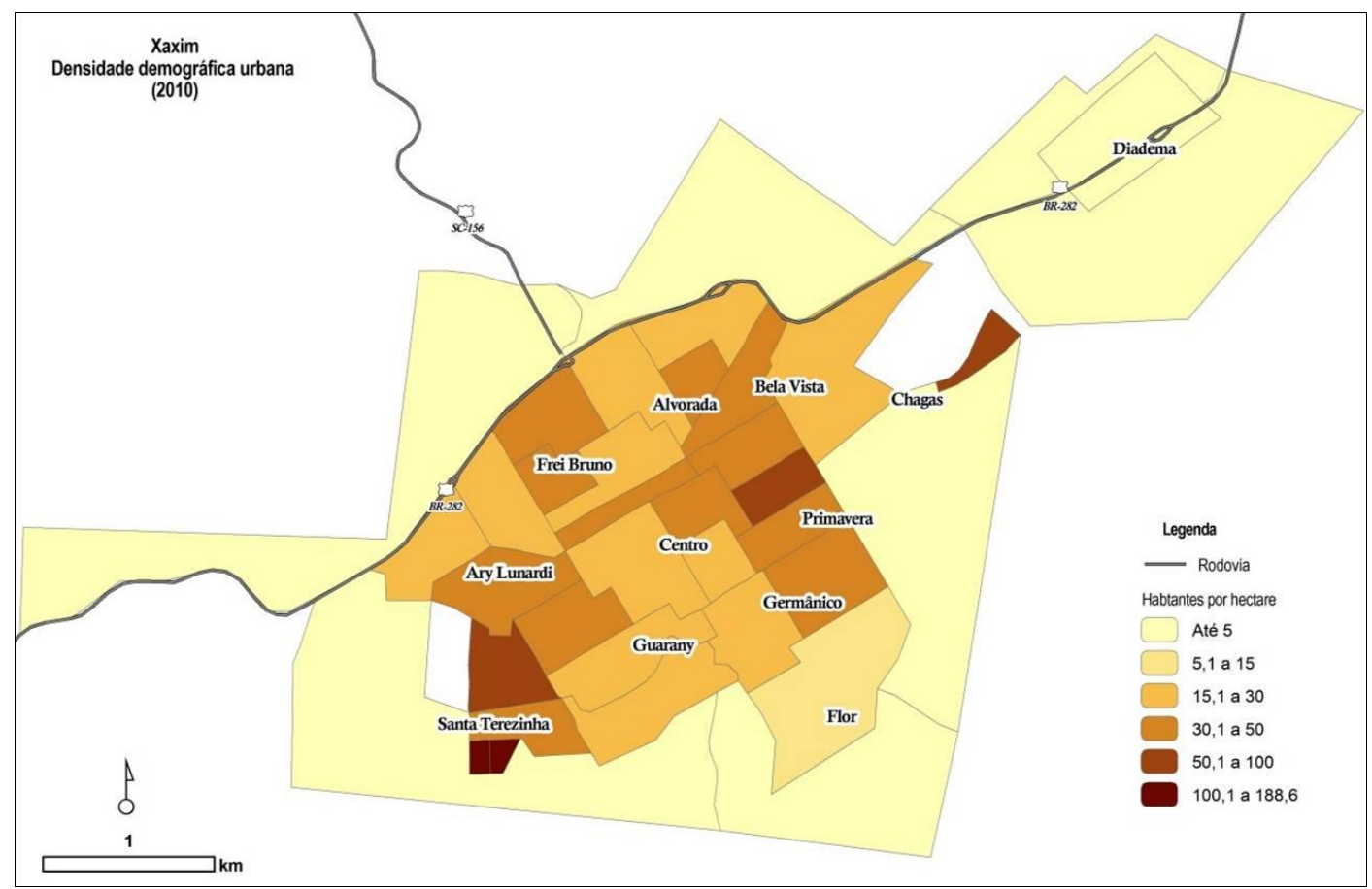

Fonte: IBGE - Censo demográfico 2010.

Elaboração: Ederson Nascimento (2018).

Figura 6 - Zoneamento de uso e ocupação do solo urbano de Xaxim

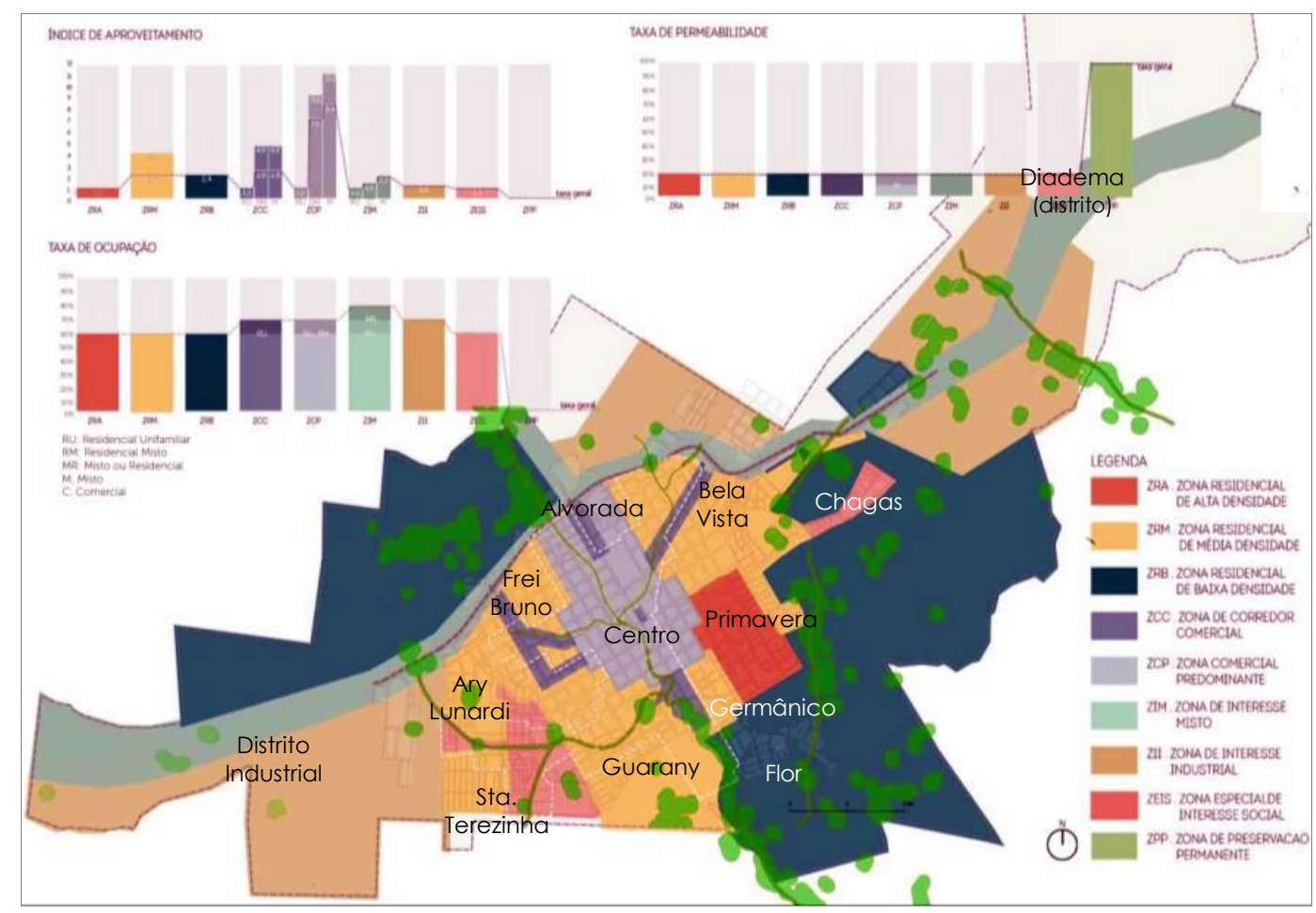

Fonte: Andrade, 2016 (adaptado pelos autores). 
O Centro e partes dos bairros Alvorada, Primavera, Guarany, Germânico e Ary Lunardi adjacentes àquele, constituem a área mais valorizada e mais bem-dotada de infraestrutura e serviços da cidade. Por essa razão, é a porção do espaço urbano na qual se concentram as camadas de renda mais elevada. Nessa área, em 2010, a soma do rendimento médio mensal de todos os responsáveis por domicílios superava o valor de quatro salários mínimos ${ }^{9}$ (Cf. Figura 7). Trata-se de populações residentes em moradias de padrão de construção mais elevado e em edifícios de apartamentos (Figura 8).

Figura 7 - Rendimento médio mensal dos responsáveis por domicílios particulares permanentes - setores censitários urbanos de Xaxim

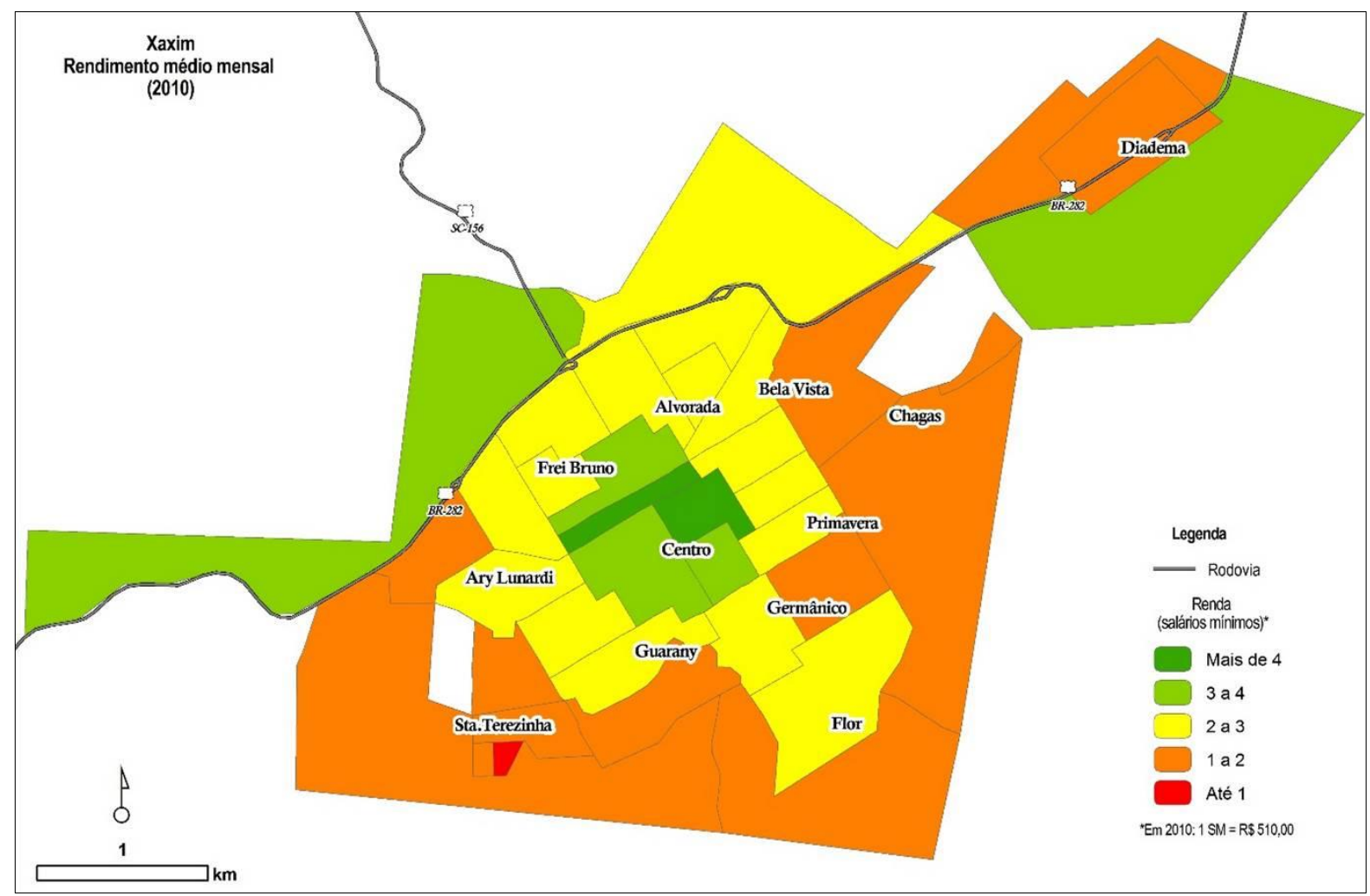

Fonte: IBGE - Censo demográfico 2010. Elaboração: Ederson Nascimento (2018).

\footnotetext{
${ }^{9}$ Os setores censitários nos extremos oeste e nordeste da área urbana registrados com renda média de 3 a 4 salários mínimos (Cf. Figura 7), correspondem a áreas com pouca população e baixas densidades de ocupação, com predomínio de chácaras.
} 
Figura 8 - Vista da rua Senador Nereu Ramos, sentido leste-oeste, entre os bairros Primavera (primeiro plano) e Centro (porção central da foto)

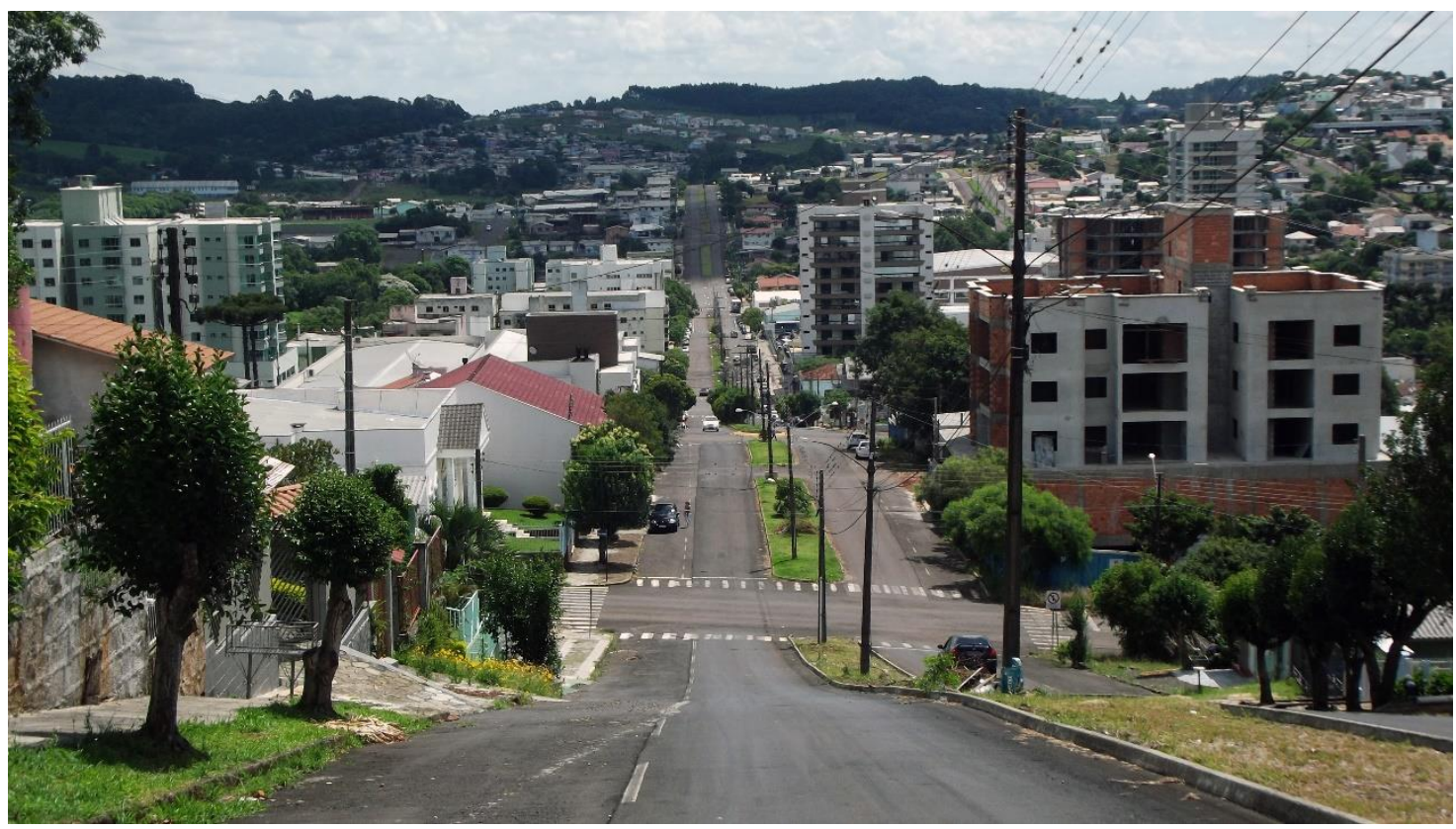

Foto: Ederson Nascimento (2017).

Nas demais zonas da cidade (Cf. Figura 6) predomina o uso residencial, com elevadas densidades de ocupação (incentivadas pelo zoneamento em vigor) nas já citadas ZCP e ZCC, bem como na ZRA (Zona Residencial de Alta Densidade), que envolve áreas adjacentes ao Centro nos bairros Primavera e Germânico. A espacialização dos níveis médios de renda (Figura 7) nos dá uma ideia do perfil socioeconômico da população nesses bairros ${ }^{10}$. Observa-se que ao redor do núcleo central de camadas de mais alta renda, forma-se um "cinturão" de áreas residenciais de estrato imediatamente inferior (dois a três salários mínimos). As camadas mais pobres distribuem-se no distrito de Diadema e nos loteamentos limítrofes da malha urbana contínua a leste (do bairro Bela Vista ao bairro Flor) e sul-sudoeste (do bairro Flor ao Santa Terezinha).

A infraestrutura urbana também é bastante díspar entre os bairros. Em relação ao saneamento básico, a cidade (assim como todo o município) registra 100\% de oferta de

\footnotetext{
${ }^{10}$ Apesar de os dados censitários utilizados para esta análise, provenientes do censo demográfico de 2010, já terem considerável defasagem temporal, acredita-se, a partir da realizada observa in loco, que o perfil socioeconômico indicado para as áreas da cidade corresponda, em sua maior parte, ao existente na atualidade.
} 
água via rede geral pela Companhia Catarinense de Águas e Saneamento (CASAN). Entretanto, o esgotamento sanitário adequado está presente apenas parcialmente nos bairros mais periféricos, de acordo com dados do último censo demográfico (Figura 9). A pavimentação viária também é precária em parte dos loteamentos mais distantes da área central, no bairro Chagas e, principalmente, no Santa Terezinha, onde a maioria das ruas é bastante estreita e sem instalações adequadas para possibilitar o escoamento de águas pluviais, além de inexistir cobertura em algumas delas ${ }^{11}$.

Santa Terezinha é o bairro em que há o maior acúmulo de carências e precariedades em Xaxim, com grande concentração de sub-habitações e casas de baixo padrão construtivo, adensadas em terrenos de pequena metragem quadrada (Figura 10). Conforme já dito, a condição de exclusão social no local tem origem ainda quando de sua criação no fim da década de 1970, a partir da remoção de famílias da área central. Remoção esta que fora realizada para um local distante e, à época, isolado do restante da cidade, promovida muito mais com o intuito de "esconder" o que era considerado "problema" para a cidade, do que para melhorar as condições de vida daquela população. Desde então, o bairro cresceu tendo reforçada sua condição socioespacial de segregado e socialmente excluído, pois seguiu abrigando populações pobres com baixo nível socioeconômico, mas recebeu pouca atenção pelo poder público municipal, o que fez com que as carências sociais e espaciais se acumulassem e se imbricassem cada vez mais $^{12}$.

\footnotetext{
${ }^{11}$ Até 2012, apenas uma pequena parte das ruas do bairro Santa Terezinha era coberta com calçamento, sendo que o restante não tinha nenhum tipo de pavimentação. A partir do referido ano, houve o asfaltamento de mais de $80 \%$ dessas vias.

${ }^{12}$ No âmbito da expansão da área urbanizada de Xaxim, nos últimos anos outras áreas residenciais (como o loteamento São Carlos e o residencial vertical Parque das Flores) foram implantados nas proximidades do conjunto habitacional do bairro Santa Terezinha (Cf. Figura 4), os quais, segundo a delimitação oficial de bairros, pertencem ao território do bairro Santa Terezinha. Entretanto, moradores desses novos loteamentos negam essa filiação, o que remete ao estigma de se pertencer ao bairro. Para esses moradores (e muitos outros da cidade), o território do Santa Terezinha está associado diretamente à área do assentamento precário, a qual é vista, por sua vez, como "a favela", "o lugar da bandidagem", entre outros estigmas.
} 
Figura 9 - Percentual de domicílios com esgotamento sanitário adequado setores censitários urbanos de Xaxim

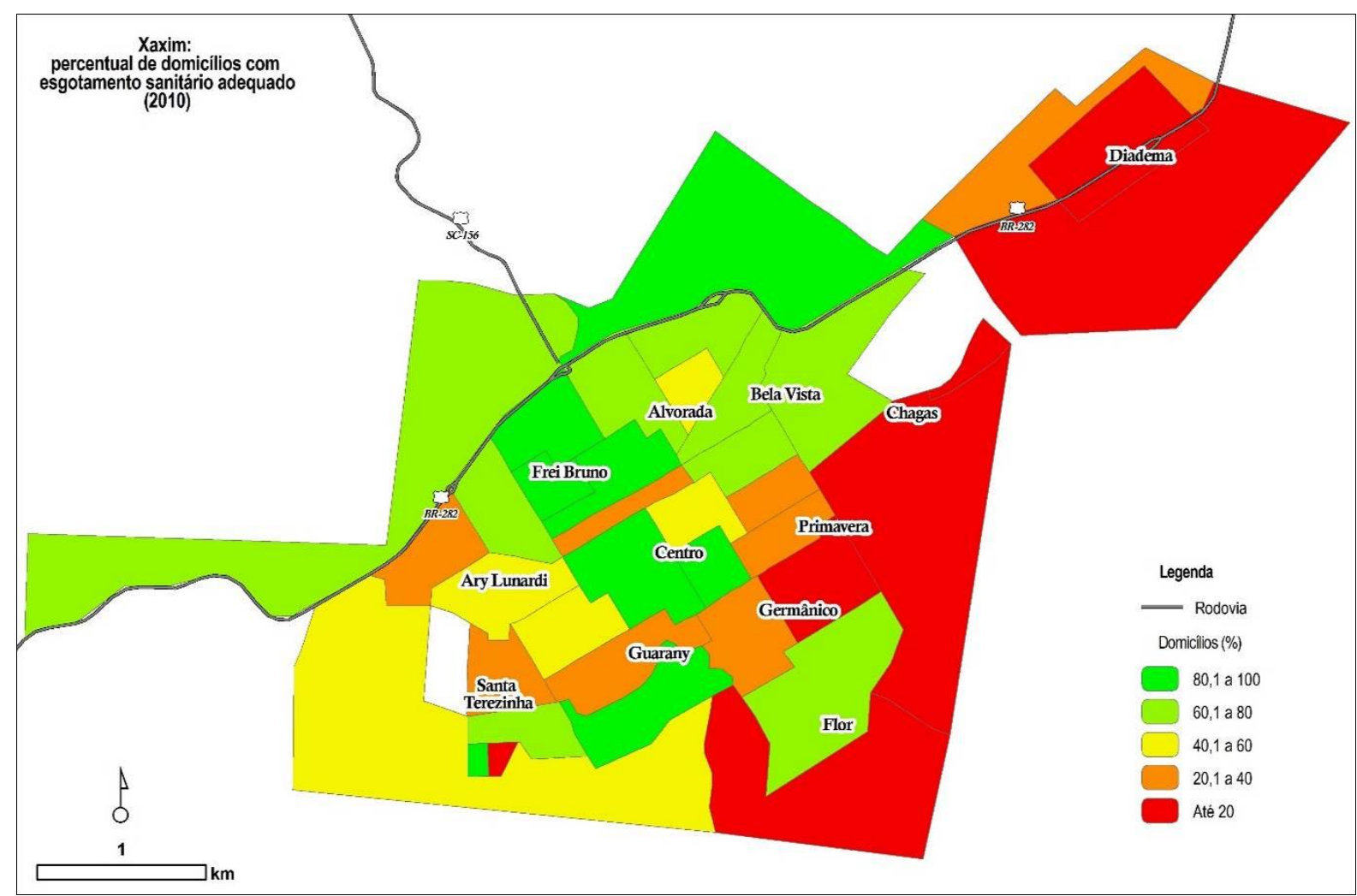

Fonte: IBGE - Censo Demográfico 2010.

Elaboração: Ederson Nascimento (2018). 
Figura 10 - Vistas da Zona Especial de Interesse Social do bairro Santa Terezinha

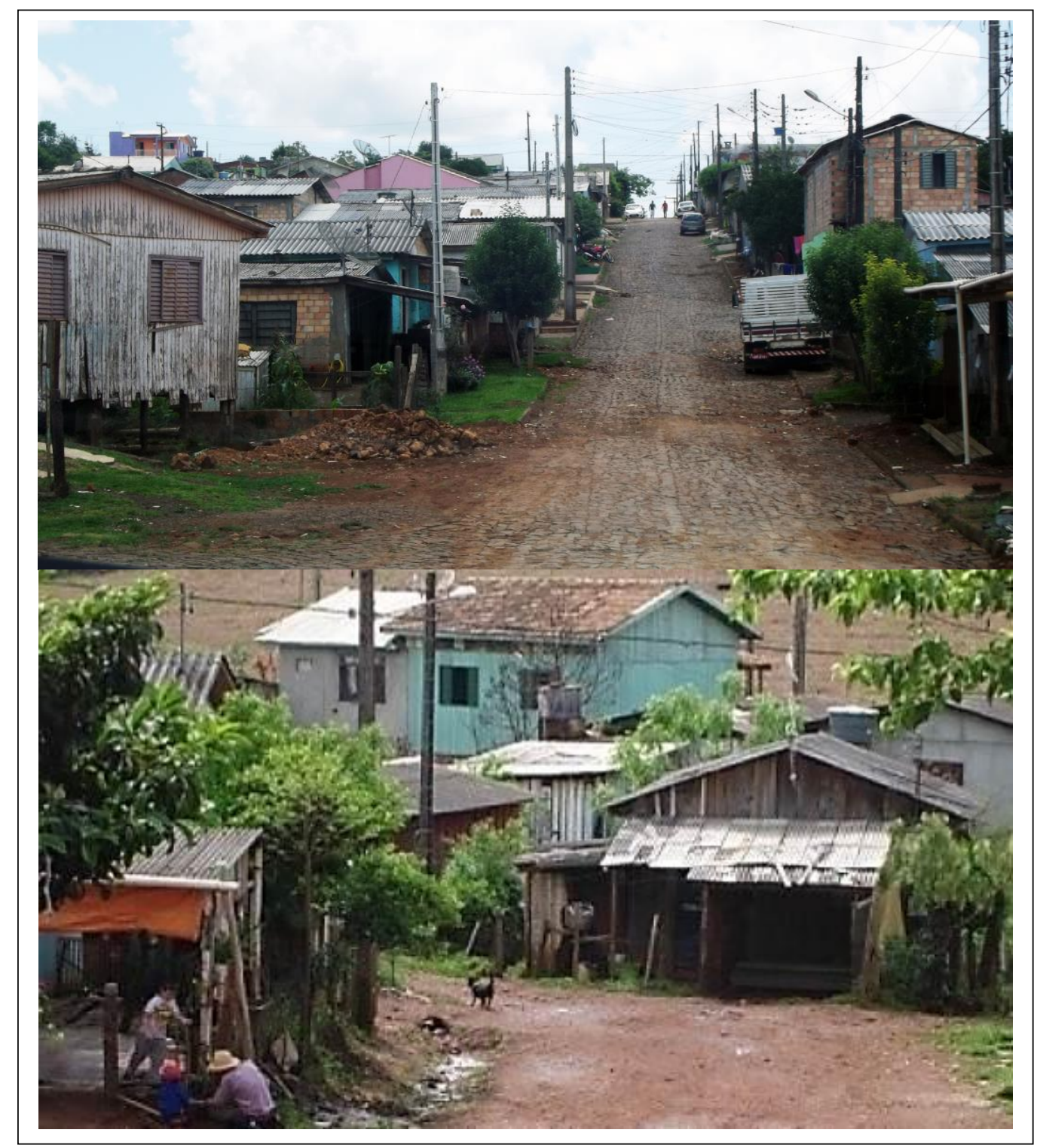

Fotos: Ederson Nascimento (2017).

Apenas mais recentemente, em meio à implantação de outros loteamentos no território do bairro, o assentamento precário do Santa Terezinha (área do conjunto habitacional empreendido pelo Estado para as famílias de baixa renda) passou a ser foco de investimentos e políticas específicas, com melhorias na infraestrutura e serviços: atualmente a população dispõe de uma escola de ensino fundamental, creche, unidade básica de saúde e um Centro de Referência em Assistência Social (CRAS). Além disso, no plano diretor de 2014, a área foi definida como Zona Especial de Interesse Social (ZEIS) 
(Cf. Figura 6), a fim de viabilizar a regularização fundiária e a dotação de investimentos públicos (XAXIM, 2014).

Em relação à promoção da habitação para camadas de baixa renda, algumas ações foram empreendidas pelo município nos últimos quatro anos, após um hiato de quase uma década - as últimas moradias entregues pelo poder público municipal tinham sido em 2005 -, utilizando-se de recursos de programas federais (Programa de Aceleração do Crescimento - PAC, fases I e II, e Minha Casa Minha Vida - MCMV). De acordo com informações da Prefeitura Municipal de Xaxim, foram entregues 32 apartamentos e 18 casas no bairro Bela Vista, 94 casas no bairro Chagas (loteamento Santa Bárbara), além de outras 34 casas no bairro Santa Terezinha. Essas unidades foram destinadas a famílias registradas no cadastro habitacional da Prefeitura Municipal, segundo critérios socioeconômicos. Também no bairro Santa Terezinha, em uma área nas proximidades da ZEIS, foi construído um grande residencial horizontal unifamiliar, denominado como Condomínio Parque das Flores, com 224 apartamentos de 54,5 m² cada.

A entrega dessas habitações apenas ameniza a demanda por moradia em Xaxim. Em 2014, de acordo com a Prefeitura Municipal, o déficit habitacional no município era estimado em mil residências. No último levantamento mais detalhado, publicado em 2011 pela antiga Companhia de Habitação de Santa Catarina - COHAB/SC, o déficit para o município era de 700 residências (100 na área rural e 600 na área urbana), sendo que dessas 600, 500 correspondiam a famílias de baixa renda (até três salários mínimos) (COMPANHIA DE HABITAÇÃO DE SANTA CATARINA, 2018).

Outro fator digno de nota é a condição de segregação socioespacial à qual as populações mais pobres vão progressivamente sendo acometidas no espaço urbano local. Isso ocorre principalmente porque: a) tanto as áreas residenciais mais antigas, como as novas destinadas a essas camadas, têm se concentrado nas periferias leste e sulsudoeste, distanciando-se dos principais locais de trabalho e consumo na cidade (o Centro principal, o distrito industrial e áreas lindeiras à BR-282 no quadrante noroeste da área urbana), e; b) não há serviço de transporte coletivo urbano no município, o que impõe severas limitações de mobilidade e acessibilidade a essa população socioespacialmente periférica. 


\section{Considerações finais}

Procurou-se, com este trabalho, fornecer uma contribuição ao conhecimento científico sobre a cidade de Xaxim, realizando-se uma análise de sua formação históricogeográfica e de suas principais desigualdades socioespaciais. A análise aqui empreendida, é claro, não esgota esse amplo tema - e tampouco teve-se tal pretensão. Outras dimensões da desigualdade que não puderam ser abordadas aqui, podem e devem ser alvo de outras pesquisas futuras, caso dos diferenciais de acesso à saúde e à educação, e da vulnerabilidade à criminalidade, entre outros exemplos.

A despeito disso, os dados e informações levantados permitiram demonstrar como, em um núcleo urbano de pequeno porte, com população de pouco mais de 20 mil habitantes, as características da organização espacial e os perfis socioeconômicos da população podem ser amplamente distintos e, mais do que isso, socialmente díspares e injustos. À guisa de síntese, pode-se afirmar que na cidade de Xaxim, especificamente em relação às áreas residenciais, os níveis de desigualdade socioespacial demarcam de modo mais evidente três subespaços: a) a área central, formada pelo centro e partes de bairros vizinhos subjacentes àquele, área esta a mais valorizada, mais bem dotada de infraestrutura e serviços e que concentra as classes de mais alta renda; b) a área aqui denominada como assentamento precário do bairro Santa Terezinha, o local com maior nível de precariedade material e infraestrutural e de mais elevada exclusão social da população, e; c) as demais áreas residenciais, que combinam níveis de organização espacial e perfis socioeconômicos distintos (uns melhores do que outros), porém medianos, isto é, com condições intermediárias às encontradas nos "polos" representados pelos outros dois subespaços.

As condições precárias de habitabilidade e a subjugação da cidadania pela condição de mercadoria assumida pela terra urbana e pelo espaço construído, que em Xaxim, assim como em grande parte das cidades brasileiras, não tem seus efeitos suficientemente contrabalançados por políticas urbanas - como a dotação, pelo poder público, de investimentos em infraestrutura e serviços de modo equilibrado socioespacialmente, e a aplicação de instrumentos de política urbana para recuperação 
de parte da valorização imobiliária proveniente de investimentos públicos - e sociais como, por exemplo, ações mais duradouras de promoção da moradia para camadas de baixa renda. Em tal contexto, as condições - recursos, oportunidades, passivos e riscos para se viver ( $\mathrm{n}$ )a cidade são também desiguais.

A busca por reduzir tais disparidades sociais na apropriação e uso do espaço urbano é, portanto, algo fundamental para a produção de uma cidade mais equânime e com condições de vida adequadas para toda sua população.

\section{Referências}

ALBA, Rosa Salete. Espaço urbano: os agentes da produção em Chapecó. 2. ed. Chapecó: Argos, 2013.

ALVES, Pedro Assumpção; MATTEI, Lauro Francisco. Migrações no Oeste catarinense: história e elementos explicativos. In: ENCONTRO NACIONAL DE ESTUDOS POPULACIONAIS, 15, Caxambu. Anais [...] Caxambu: ABEP, 2006.

AGÊNCIA NACIONAL DE ÁGUAS. Atlas esgotos. Brasília: Agência Nacional de Águas: Secretaria Nacional de Saneamento Ambiental, 2017. Disponível em http://www.snirh.gov.br/portal/snirh/snirh-1/atlas-esgotos. Acesso em: 21 out. 2018.

ANDRADE. Sheila Patrícia de. A urbanidade oculta: uma reconciliação entre as águas urbanas e os espaços livres em Xaxim (SC). Erechim: UFFS, 2016. (Projeto arquitetônico).

BELLANI, Eli. Balsas e balseiros no Rio Uruguai. Cadernos do CEOM, Chapecó, n. 23, p. 7397, 2014.

BRASIL. Ministério do Desenvolvimento Social. Cadastro único. Disponível em: http://mds.gov.br/assuntos/bolsa-familia/dados/dados. Acesso em: 23 jul. 2016.

CHITOLINA, Valdirene. Velho Xaxim. 2. ed. Chapecó: Argos, 2015.

CHITOLINA, Valdirene. Xaxim postal. Chapecó: Argos, 2016.

COMPANHIA DE HABITAÇÃO DE SANTA CATARINA. PCHIS - Diagnóstico habitacional: déficit habitacional por município. Disponível em: http://intranet.cohab.sc.gov.br/ cohab/pchis/consultas/mun_deficit.asp?ordem=0\&faixa=0. Acesso em: 08 jul. 2018. 
CORRÊA, Roberto Lobato. Trajetórias geográficas. Rio de Janeiro: Bertrand Brasil, 1997.

CORRÊA, Roberto Lobato. Diferenciação sócio-espacial, escala e práticas espaciais. Cidades, Presidente Prudente, v. 4, n. 6, p. 62-72, 2007.

COSTA, Alfredo Bruto da. Exclusões sociais. Lisboa: Gradiva, 1998.

CURTARELLI, Ledinho. Depoimento. [Entrevista cedida a] Miriam Pegoraro, Xaxim, 10 out. 2017.

IBGE. INSTITUTO BRASILEIRO DE GEOGRAFIA E ESTATÍSTICA. Censo demográfico 2010. Rio de Janeiro: IBGE, 2012. Disponível em: https://ww2.ibge.gov.br/home/estatistica/ populacao/censo2010/default.shtm. Acesso em: 28 ago. 2017.

LÊ NOTÍCIAS. Quebra dos frigoríficos Chapecó e Diplomata deixou xaxinenses em agonia plena. 06/09/2017. Disponível em: http://www.lenoticias.com.br/noticia/1845/quebra-dosfrigorificos-chapeco-e-diplomata-deixou-xaxinenses-em-agonia-plena. Acesso em: 12 ago. 2018.

MARICATO, Erminia. Para entender a crise urbana. São Paulo: Expressão Popular, 2015.

MATOS, Ralfo. Desigualdades socioespaciais: inserções teóricas e conceituais e discussão do caso brasileiro. In: MATOS, Ralfo; SOARES, Weber (orgs.). Desigualdades, redes e espacialidades emergentes no Brasil. Rio de Janeiro: Garamond, 2010. p. 19-57.

OLIVEIRA, Maria de. Xaxim conta sua história. Xaxim: Prefeitura Municipal, 1992.

PERTILE, Noeli. Formação do espaço agroindustrial em Santa Catarina: o processo de produção de carnes no Oeste Catarinense. 2008. 322f. Tese (Doutorado em Geografia), Centro de Filosofia e Ciências Humanas, UFSC, Florianópolis, 2008.

PIAZZA, Walter Fernando. A colonização de Santa Catarina. 3. ed. Florianópolis: Lunardelli, 1994.

PROGRAMA DAS NAÇÕES UNIDAS PARA O DESENVOLVIMENTO. Atlas do desenvolvimento humano no Brasil. Brasília: PNUD: FJP: IPEA, 2013. Disponível em: http://atlasbrasil.org.br/2013/pt/home/. Acesso em: 09 out. 2017.

RENK, Arlene. A luta da erva: um ofício étnico no Oeste Catarinense. Chapecó: Grifos, 1997. 
RODRIGUES, Arlete Moyses. Desigualdades socioespaciais - a luta pelo direito à cidade. Cidades, Presidente Prudente, v. 4, n. 6, p. 73-88, 2007.

SANTOS, Milton. A urbanização brasileira. São Paulo: Hucitec, 1993.

SANTOS, Milton; SILVEIRA, María Laura. O Brasil: território e sociedade no início do século XXI. Rio de Janeiro: Record, 2001.

SCHERER; Christine Martins; FUJITA, Camila; RIGON, Matheus José. Misturando palha e barro: um projeto de intervenção na construção de uma política pública habitacional municipal por processos de bioconstrução. In: CONGRESSO INTERNACIONAL SUSTENTABILIDADE E HABITAÇÃO DE INTERESSE SOCIAL, 2., 2012, Porto Alegre. Anais [...] Porto Alegre: EdPUC/RS, 2012.

SKRZYPCZAK. Valdir. A educação/qualificação dos trabalhadores do campo e da cidade na lógica do capital agroindustrial, na cidade de Xaxim (SC). 2013. 148f. Dissertação (Mestrado em Geografia), UNIOESTE, Francisco Beltrão, 2013.

SPOSITO, Eliseu Savério; SILVA, Paulo Fernando Jurado da. Cidades pequenas: perspectivas teóricas e transformações socioespaciais. Jundiaí: Paco Editorial, 2013.

XAXIM. Lei complementar $n^{\circ}$ 146, de 24 de novembro 2014. Institui o Plano Diretor Participativo de Desenvolvimento Municipal do município de Xaxim. Xaxim: [Câmara Municipal, 2014]. Disponível em: https://leismunicipais.com.br/plano-diretor-xaxim-sc. Acesso em: 11 dez. 2017.

Recebido em: 29/11/2018 Aprovado em: 16/05/2019

Universidade do Estado de Santa Catarina - UDESC Centro de Ciências Humanas e da Educação - FAED

Revista PerCursos

Volume 20 - Número 43 - Ano 2019 revistapercursos@gmail.com 